(1) $(9)$ This work is licenced under the Creative Commons Attribution 4.0 International license for non-commercial purposes.

\title{
[ Reading Shylock's Dream: A Pathological Miser or an Anxious Dream Interpreter? ]
}

\section{Filip Krajník}

\author{
Masaryk University, \\ Brno, Czech Republic
}

[Abstract] This study addresses the presentation and interpretation of Shylock's dream "of money-bags" in Shakespeare's The Merchant of Venice (c. 1596-1598) and George Granville's The Jew of Venice (1701). The text argues that, although verbally very similar, the two episodes should be considered within their respective dramaturgical traditions (the Elizabethan and the Restoration), as well as within the different genres into which each play falls. While Granville's rendition of the dream episode seems merely to contribute to the stereotypical image of a greedy Jew, Shakespeare's version draws on the conventional employment of dream prophecies in Renaissance tragedies and contributes not only to the unity of the play's plot, but also adds to the complexity and the tragic overtones of his Shylock.

[Keywords] William Shakespeare; The Merchant of Venice; George Granville; The Jew of Venice; dramatic dream; Elizabethan drama; Restoration drama 
In a rare case of adding to the original plot rather than reducing it, George Granville's 1701 revival of Shakespeare's The Merchant of Venice, re-titled The Jew of Venice, presents Antonio, Shylock, Gratiano and Bassanio gathered at Bassanio's house. At the beginning of this light-hearted banquet scene - which in Shakespeare's play only takes place offstage the characters merrily exchange toasts: "to immortal Friendship" (2.2.1), "to Love, and to Love's Queen; my charming Portia" (2.2.15, italics original), and "to the Sex in general; / To Woman; be she black, or brown, or fair" (2.2.23-24). When it is Shylock's turn to propose a toast, however, the titular Jew of the play shows little appreciation of his companions' spiritual values:

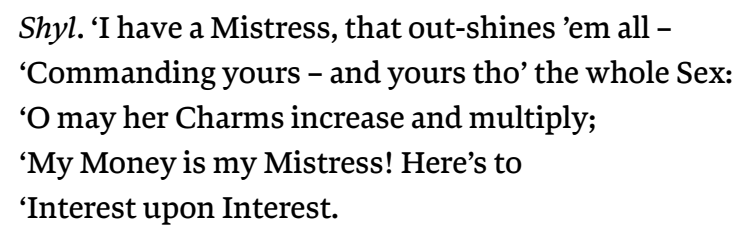

Shyl. 'I have a Mistress, that out-shines 'em all -

'Commanding yours - and yours tho' the whole Sex:

'O may her Charms increase and multiply;

'My Money is my Mistress! Here's to

'Interest upon Interest.

(2.2.27-31, inverted commas, indicating Gran-

ville's additions to Shakespeare's text, original)

The speech is very much symptomatic of the broader change that Granville's Shylock had undergone since Shakespeare's version of the story. While Shakespeare, it is generally agreed, depicted Shylock not only as a villain, but also as a "credibly complex human being" (Bulman 22) and "a motivated, tragic figure, a person robbed of everything he valued" (Craft 39), Granville's Jewish character is chiefly reduced to a buffoon, who is "sadistic" (Coleman 18), "obscenely greedy" (Calvi 64), and has "lost the individuality with which Shakespeare had imbued him" (Bulman 22). Craft maintains that, by rendering Shylock as a one-dimensional figure to be scorned and mocked by the audience, Granville "exploited the feelings of amused contempt that were directed at the small number of Jews who resided in London in 1701" (44); in a similar vein, Coleman points out that Granville himself held strong anti-Jewish sentiments for political reasons and probably "saw his Shylock as an Askenazim [sic] and vented his hatred on the group by intensifying Shylock's villainy” (33). This overall image of Granville's Jewish protagonist was certainly strengthened by the fact that, on London stages in the first half of the eighteenth century, Shylock was played by low comedians - a tradition that was only broken by the Drury Lane actor Charles Macklin, who in 1741, for the first time since the Interregnum, presented Shylock as a serious dramatic figure, to the great applause of the audience and praise from the critics (see "Macklin, Charles", 7-10).

The depiction of Shylock as a pathological miser who only thinks about his money is, at first sight, not entirely unsanctioned by Shakespeare's text. In the scene immediately preceding the banquet in Granville's play, the audience witnesses Shylock leaving his house and his daughter, expressing his misgivings over his presence at the dinner:

Shyl. I am bid forth to Supper, Jessica, There are my Keys; but wherefore should I go! 
I am not bid for Love: They flatter me, But then I'll go in Hate: To feed upon The Prodigal Christian.

I am right loath to go, there is some ill

A brewing towards me: I dreamt last Night

Of Money-bags.

\section{(2.1.1-8, italics original)}

Unlike Shylock's toast at Bassanio's, his mention of a dream about money comes almost verbatim from Shakespeare, where it precedes Jessica's elopement with her Christian lover Lorenzo (one of Antonio's companions) and her theft of her father's money. The function of the dream in Granville's play is clear: to provide yet another example of Shylock's single-mindedness. In this respect, Shylock's aforementioned later reference to his "Mistress, that out-shines 'em all" might be understood as a kind of key to his earlier dream, its interpretation for the audience, as well as an element that adds to the coherence of the dramatic character. In Shakespeare's play, too, the dream contributes to the unity of Shylock's character; given the Elizabethan tradition of the employment of dramatic dreams; however, its meaning there seems to be entirely different.

What is important to note is that, with the change in the nature of Shylock in Granville, the genre of his plot had shifted as well. In 1709, when Nicholas Rowe wrote the first critical account of Shakespeare's life and work, he pointed out that 'tho' we have seen the Play Receiv'd and Acted as a Comedy, and the Part of the Jew perform'd by an Excellent Comedian, yet I cannot but think it was design'd Tragically by the Author" (xix-xx, italics original). Indeed, while the ending of The Merchant of Venice, with Antonio's life saved and multiple weddings taking place, appears to be precisely as one would expect of a play traditionally classified as a comedy, the audience, still with fresh memories of the trial scene from the previous act, cannot help but feel a certain level of uneasiness. Just a few moments earlier, Shylock was humiliated in front of both the Venetian public and the eyes of the theatregoing audience, stripped of all his property, and ultimately forced to convert to Christianity. With a mere caricature to laugh at, this would hardly have any strong emotional impact on the audience; however, with a complex (albeit villainous) character, who, to quote Bernard Grebanier's exquisite volume The Truth About Shylock, is "entitled to respect to a degree, a man with his own dignity and perspective" (93), the same situation bears distinctly tragic overtones.

If we accept the premise that Shakespeare's The Merchant of Venice contains visible elements of tragedy, ${ }^{1}$ the ominous air of Shylock's dream, as originally presented by Shakespeare, becomes clearly visible. What should be noted when comparing Shakespeare's and Granville's plays is the fact that, unlike the Restoration stage, Elizabethan dramaturgy frequently employed dreams and visions as technical devices to foreshadow the development of the plot and generate dramatic suspense. Examples might include Lady Eleanor's dream in Shakespeare's King Henry VI, Part II, Lord Stanley's prophecy in his King Richard III, Arden's nocturnal warning in the apocryphal Arden of Faversham, or Lady More's dream vision, anticipating her husband's downfall, in the anonymous Sir 
Thomas More (see Drábek). As Bain Tate Stewart argues, the prophetic dream in Elizabethan drama that warns the dreamer against a danger or disaster of some kind is always "reasonably clear to the audience, though it is rejected by the dreamer or by the person to whom the dream refers" (203). Such a dream, Stewart continues, is related to a recurrent theme of early modern English tragedies, i.e. "the sense of the nobility of man and certainty of his fate"; at the same time, it is also a great illustration of the dramatic irony "of man's inability to recognize his fate even if it is, symbolically, revealed to him" (206).

Could Shylock's dream of money bags be such a symbolic warning, which Elizabethan audiences might have understood whereas the character on the stage was too ready to dismiss it and fail to prevent the imminent tragedy? At the end of the sixteenth century, belief in prophetic dreams and dream symbols was still widespread in England. The Elizabethan popularizer of sciences Thomas Hill, in his treatise The Moste Pleasaunte Arte of the Interpretacion of Dreames (1559), ${ }^{2}$ called significative dreams (that is, dreams providing some special knowledge about the future) true ones, asserting that they "foreshewe al matters imminent" and defend the dreamers "from the instant euiles $\&$ perils, or [move them] to the attayninge of good things to come" (sig. [A2]v, contraction expanded). Keith Thomas argues that Elizabethans tended to attach much significance to dream omens; as he notes, dream interpretation "was one of the services performed by wizards and astrologers to their clients and there were sundry magical formulae for procuring divinatory dreams" (153). Furthermore, in the second half of the sixteenth century, England witnessed a steady influx of popular dream interpretation manuals appearing in cheap printings, some of which are only known today by their titles. ${ }^{3}$ It might be assumed that these manuals circulated among the common readership of the period, including London theatregoers. On top of these, educated elites also had access to both classical and humanistic Latin works on dreams, imported from the Continent.

Scrutiny of some of these dream treatises reveals that the dream of money was indeed a frequent and established topos, and was universally taken as a bad sign. Artemidorus, whose Oneirocriticon (second century AD) had circulated in Europe in several languages from 1518 and was first printed in English in 1606 (reaching its twenty-fourth edition by 1740), observes that "to dreame of money and all kinde of coyne is ill" and writes that such a dream signifies "heavinesse and angry words", especially when the money is in the form of gold or silver and in large quantities, since "one cannot employ great heapes, without payne and care" (99-100). The Somniale Danielis, the most popular mediaeval dreambook, whose contents would still have been common knowledge in the early modern period, connects seeing money in one's sleep with a lawsuit (Peccuniam accipere, litem significat), heaviness, derision or vituperation (Si uideris plures denarios aut inuenies, parabolas uel irrisiones uel maledictiones significat), anger (Denarios tractare significat iracundium) (Fischer 102), as well as with hatred (Denarios invenire: oidum significat) (Martin 87). The popular ninth-century Byzantine dream interpretation manual known as the Oneirocriticon Achmetis argues that the dream of money means quarrels, lawsuits and sorrow (Si viderit quis se inuenisse minuta aeris, inueniet rixas $\mathcal{E}$ lites $\mathcal{E}$ aerumnas pro ratione minutorum) (Achmetis F. Seirim Oneirocritica, 237). Finally, Gierolamo Cardano, in the 
most concise humanistic work on dreams, Somniorum Synesiorum Libri IIII (1562), warns that seeing coins in a dream points to a quarrel or lawsuit (Nummi aerei rixam aut litem ostendunt) (57). Surprisingly (or perhaps not so surprisingly), all the omens of the dream manuals exactly fit the situations which Shylock will encounter later on in the play, foretelling both the trial scene and Shylock's ultimate fall.

Equally striking is the similarity between the plot of the play and certain interpretations of the dream of gold, which was considered so close to the dream of money by the authors of dreambooks that some of them even interpreted the two topoi together (after all, a Venetian ducat was made of gold, as Shakespeare himself mentions in 2.6.49-50). Artemidorus, on the one hand, admits that "to dreame to have gold is not bad, because of the matter, as every one wil say, but contrariwise it is good as I have knowne by experience" (61); at the same time, however, he also gives an example of when a dream of gold may be dangerous: "Losse of rings to a man, signifies not onely the losse of them that had charge over his goods, as the wife, the tennant $\&$ c. but also loss of his goods, landes and possessions" (62). Despite the fact that Shylock dreams of gold in the form of money, not jewellery, the symbol of a lost ring does occur several times in the play: Shylock loses a ring from his late wife when Jessica steals it from him (3.1), and later on, Portia and Nerissa use rings to test their husbands' fidelity (4.2). The dream of gold in Shylock's situation might, therefore, faithfully tell him about "the losse of them that had charge over his goods" - that is, his servant Lancelot, who leaves his household for Bassanio's (2.2), and his daughter, who elopes with Lorenzo (2.6). It might also warn him against the "loss of his goods, landes and possessions”, either presaging Jessica's theft of his money when she escapes or the forfeiture of his property by sentence of the court.

It would, of course, be somewhat naïve and simplistic to claim that Shakespeare had intimate knowledge of all the aforementioned dreambooks or that he directly used them when writing his play, but considering the popularity of dreams and dream interpretation in the environment in which The Merchant of Venice was originally written and received, the stability of money as a distinct dream topos throughout the centuries (even across cultures), and the dramaturgical conventions of late sixteenth-century English theatre, it might be assumed that Shakespeare intentionally presented Shylock's dream as a dramatic prophecy, hinting at the future development of the story. By doing this, he not only contributed to the unity of the story (the dream foregrounds the theme of money, common to both the main plot and the sub-plot of the play), but also imbued Shylock with a distinctively tragic quality, as the audiences expect his downfall as revealed to them by means of the dream prophecy.

The same cannot, however, be said about attitudes to dreams in post-Restoration England and Europe in general. Indeed, although references to significative dreams kept appearing in seventeenth-century English commonplace books, ${ }^{4}$ it seems that their credit did fade quickly from the end of the sixteenth century. As Mary Baine Campbell records, when Dorothy Osborne (1627-1695), in the early 1650s, mentioned dreams in love letters to her future husband, Sir William Temple (1628-1699), she never forgot to dismiss the topic, considering (in Campbell's words) even private correspondence as "too elevated 
a genre to include this junk" (27). In a similar vein, Alice Browne has written perceptively about René Descartes (1596-1650) and the famous series of three dreams which he had on the night of 10-11 November 1619. Whereas the youthful Descartes of 1619, going through personal, intellectual and spiritual crises, yearned for revelatory dreams in order to find a direction for his shapeless future, and having finally experienced them, took pains to set them down in writing and interpret them, all his references to dream phenomena from his later life were, as Browne observes, "thoroughly naturalistic, assimilating them to other deceptions of the senses" (259).

It is reasonable to assume that with this cultural shift - along with the loss of popularity of pre-Interregnum tragedies and their dramatic language in general - neither Granville nor the post-Restoration audience would have read Shylock's dream as a foreboding prophecy. A small but significant hint might be found in Shylock's language when mentioning his dream vision to Jessica. While Shakespeare's Shylock explicitly makes a link between his uneasiness to leave the house and his recent dream experience, claiming that "... I am right loath to go, / There is some ill a-brewing towards my rest, / For I did dream of money-bags to-night" (2.5.16-18, emphasis mine), Granville's Shylock is less explicit about the dream being the reason for his misgivings: "I am right loath to go, there is some ill / A brewing towards me: I dreamt last Night / Of Money-bags" (2.1.6-8). If anything, the Restoration presentation of the dream fits the image of "a Stock-jobbing Jew" - as the "Ghost of Shakespear" describes Shylock in the Prologue to The Jew of Venice (1. 29, italics original) - who is only waiting for his punishment according not to any supernatural power that, in the Renaissance world-view, governed man's destiny, but to the neoclassical rules of poetic justice that dominated late early modern English drama and theatre.

\section{[Notes]}

1 It is noteworthy that, while the title page of the 1701 edition of Granville's The Jew of Venice announces the play as "a Comedy", the 1600 quarto of Shakespeare's The Merchant of Venice designates the play more broadly as "The most excellent Historie".

2 The oldest surviving fragment (the title page) is from 1571, and the oldest surviving complete copy is from 1576. For the publication history of The Moste Pleasaunte Arte, see Johnson 342.

3 Anon., Here Begynneth the Dreames of Daniell (1556?, STC [2 ${ }^{\text {nd }}$ ed.] 6235.5); Thomas Hill, A Most Briefe and Pleasant Treatise of the Interpretation of Sundrie Dreames (1567, STC

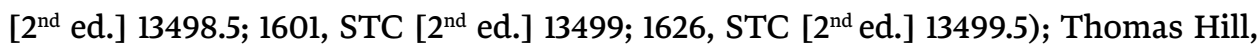
The Moste Pleasaunte Arte of the Interpretacion of Dreames (1559, lost; 1563, lost; 1567, lost; 1571, STC [ $2^{\text {nd }}$ ed.] 13497.5; 1576, STC [2nd ed.] 13498); Anon., Diall of Dreames, Judicially Poynting to the Successe that Folowes Euery Fancie Appearing in Sleepe (1590, lost); Artemidorus, The Judgement, or Exposition of Dreames (1606, STC [ $2^{\text {nd }}$ ed. $\left.] 795\right)$.

4 See Hodgkin 104; for a discussion of an early seventeenth-century commonplace book containing a catalogue of dream prognostics, see Masten. 


\section{[Bibliography]}

Achmetis F. Seirim Oneirocritica. In Artemidori Daldiani \& Achmetis Sereimi F. Oneirocritica. Paris: Marc Orry, 1603.

Artemidorus. The Judgement, or Exposition of Dreames. Trans. Robert Wood. London: William Jones, 1606.

Browne, Alice. "Descartes's Dreams.” Journal of the Warburg and Courtauld Institutes 40 (1977): 256-73.

Bulman, James C. Shakespeare in Performance: The Merchant of Venice. Manchester: Manchester UP, 1991.

Calvi, Lisanna. “'This may appear unmanly Tenderness': Homosocial Bonds and (Un) ruly Women in George Granville's The Jew of Venice (1701).” Theatralia 24.1 (2021): 61-77.

Campbell, Mary Baine. "Dreaming, Motion, Meaning: Oneiric Transport in Seventeenth-Century Europe." In Reading the Early modern Dream: The Terrors of the Night. Ed. Katharine Hodgkin, Michelle O'Callaghan and S. J. Wiseman. New York: Routledge, 2008. 15-30.

Cardanus, Hieronymus. Somniorum Synesiorum omnis generis insomnia explicates, Libri IIII. Basel: Sebastian Henricpetri, 1585.

Coleman, William S. E. "Post-Restoration Shylocks Prior to Macklin". Theatre Survey 8.1 (1967): 17-36.

Craft, Catherine A. “Granville's Jew of Venice and the Eighteenth-Century Stage.” Restoration and Eighteenth Century Theatre Research 2.2 (1987): 38-54.

Drábek, Pavel. “'My Dreams Presage Too True': Dreams as Dramatic Device in Elizabethan Drama.” In Szekspiromania: księga dedykowana pamięci Andrzeja Żurowskiego. Ed. Anna Cetera. Warsaw: Wydawnictwa Uniwersytetu Warszawskiego, 2013. 247-59.

Fischer, Steven R., ed. The Complete Medieval Dreambook: A Multilingual, Alphabetical Somnia Danielis Collation. Bern: Peter Lang, 1982.

Granville, George. The Jew of Venice. Five Restoration Adaptations of Shakespeare. Ed. Christopher Spencer. Urbana: U of Illinois P, 1965. 345-402.

Grebanier, Bernard. The Truth About Shylock. New York: Random House, 1962.

Hodgkin, Katharine "Dreaming Meanings, Some Early modern Dream Thoughts." In Reading the Early modern Dream: The Terrors of the Night. Ed. Katharine Hodgkin, Michelle O'Callaghan and S. J. Wiseman. New York: Routledge, 2008. 109-24.

Johnson, Francis R. “Thomas Hill: An Elizabethan Huxley.” Huntington Library Quarterly 7 (1944): 329-51.

"Macklin, Charles." In A Biographical Dictionary of Actors, Actresses, Musicians, Dancers, Managers \& Other Stage Personnel in London, 1660-1800. Vol 10. Ed. Philip H. Highfill, Jr., Kalman A. Burnim and Edward A. Langhans. Carbondale: Southern Illinois UP, 1984. 2-27.

Martin, Lawrence T., ed. Somniale Danielis: An Edition of a Medieval Latin Dream Interpretation Handbook. Frankfurt am Main: Peter Lang, 1981. 
Masten, Jeffrey. “The Interpretation of Dreams, Circa 1610.” In Historicism, Psychoanalysis, and Early Modern Culture. Ed. Carla Mazzio and Douglas Trevor. New York: Routledge, 2000. 157-85.

Rowe, Nicholas, ed. The Works of William Shakespeare. Vol. 1. London: Jacob Tonson, 1709.

Shakespeare, William. The Merchant of Venice. Ed. John Russell Brown. 1955. Walton-onThames: Nelson, 1997.

Stewart, Bain Tate. "The Misunderstood Dreams in the Plays of Shakespeare and His Contemporaries." In Essays in Honor of Walter Clyde Curry. Nashville: Vanderbilt UP, 1954. 197-206.

Thomas, Keith. Religion and the Decline of Magic. 1971. Harmondsworth: Penguin Books, 1980.

\section{[Acknowledgement]}

This article was supported by the Czech Science Foundation project GA19-07494S, "English Theatre Culture 1660-1737".

\section{[Address]}

Department of English and American Studies,

Faculty of Arts, Masaryk University

Arna Nováka 1

60200 Brno

Czech Republic

filip.krajnik@phil.muni.cz

Filip Krajnik is a lecturer in English literature at the Department of English and American Studies, Faculty of Arts, Masaryk University in Brno, Czech Republic. His main research interests are late medieval English poetry and early modern English theatre. He is currently co-editing a volume on medieval female piety entitled Women Across Borders. He is currently the principal investigator of a Czech Science Foundation project examining late early modern English theatre as a transnational and multi-genre phenomenon; an edited volume, tentatively entitled Forms, Identities and Inspirations in Restoration Theatre, is expected in 2022. 